\title{
A mikrobiom szerepe a fül-orr-gégészetben
}

\author{
Fekete Szilvia dr. ${ }^{1}$ - Szabó Dóra dr. ${ }^{2}$ \\ Tamás László dr. ${ }^{1}$. Polony Gábor dr. ${ }^{1}$
}

${ }^{1}$ Semmelweis Egyetem, Általános Orvostudományi Kar, Fül-Orr-Gégészeti és Fej-Nyaksebészeti Klinika, Budapest ${ }^{2}$ Semmelweis Egyetem, Általános Orvostudományi Kar, Orvosi Mikrobiológiai Intézet, Budapest

\begin{abstract}
Egészségünket a szervezetünkben és a bőrünkön élő sokszínű mikrobaközösség jelentősen meghatározza. A normálflóra tagjai közötti egyensúly elengedhetetlen az egészség fenntartásában. Az újgenerációs szekvenálás gyors, szenzitív módszer, amely a mikrobiom egészének vizsgálatára alkalmas előzetes hipotézis nélkül, és információt ad a rezisztenciáról és a virulenciáról is. Ennek a módszernek a segítségével lehetôvé vált betegségekben a patogén baktériumok, illetve az ezek szaporodását gátló, úgynevezett protektív baktériumok azonosítása. A mikrobiom változásainak feltérképezése segít új terápiás célpontok meghatározásában és az antibiotikumok célzott kiválasztásában. Széles spektrumú antibiotikum használatakor a normálflóra hasznos tagjai is kipusztulnak, ami visszatérő vagy krónikussá váló fertőzések kialakulásához vezet. A fül-orr-gégészeti infekciók a leggyakoribb fertőző betegségek az emberi szervezetben és az antibiotikum alkalmazásának vezető okai világszerte. Az egészséges emberben, illetve a fül-orr-gégészeti betegségekben előforduló baktérium-összetétellel kapcsolatban számos molekuláris biológiai vizsgálat történt az utóbbi években. A szerzők ismertetik az egyes fül-orr-gégészeti anatómiai régiók normálflórájának tagjait, és különböző patológiás állapotokban a baktérium-összetétel változásait is összefoglalják.
\end{abstract}

Orv Hetil. 2019; 160(39): 1533-1541.

Kulcsszavak: mikrobiom, antibiotikum, középfül, orrüreg, garat

\section{The role of the microbiome in otorhinolaryngology}

Our health is highly determined by the diverse microbial community living within our body and upon our skin. Balance among the members of the commensal microbiota is essential for the preservation of health. New generation sequencing is a rapid, sensitive method for determining the whole microbiome without prior hypothesis and also gives information on the resistance and virulence status. Application of this method can help to identify the pathogens contributing to different diseases, and also the protective bacteria inhibiting their growth. Detecting the changes of the microbiome helps to identify new therapeutic targets and establish targeted antibiotic therapy. Broad-spectrum antibiotics also act against the beneficial members of the microbial flora, which may lead to the development of recurrent or chronic disease. Ear, nose and throat infections are the most common infective diseases in humans and the leading cause for antibiotic prescription worldwide. In recent years, many studies using molecular biology methods were performed examining the microbiome of healthy humans and in otorhinolaryngologic diseases. In the present work, the authors review the changes of the microbiological communities in the healthy state and in various pathologic states in the anatomic regions of the ear, nose and throat.

Keywords: microbiome, antibiotic, middle ear, nasal cavity, pharynx

Fekete Sz, Szabó D, Tamás L, Polony G. [The role of the microbiome in otorhinolaryngology]. Orv Hetil. 2019; 160(39): 1533-1541.

(Beérkezett: 2019. február 18.; elfogadva: 2019. március 11.)

\section{Rövidítések}

$16 \mathrm{~S}$ rRNS = $16 \mathrm{~S}$ riboszomális ribonukleinsav; DNS = dezoxiri bonukleinsav; EBV = Epstein-Barr-vírus; IgE = immunglobu- lin E; MRSA = meticillinrezisztens Staphylococcus aureus; $\mathrm{PCR}=$ (polymerase chain reaction) polimeráz-láncreakció; $\mathrm{RNS}=$ ribonukleinsav; $\mathrm{rRNS}=$ riboszomális ribonukleinsav 
Egészségünket a szervezetünkben és a bőrünkön élő sokszínú mikrobaközösség jelentősen meghatározza. A commensalis, symbionta, illetve patogén mikrobák (baktériumok, vírusok, gombák, protozoonok) Ron Sender számításai szerint együttesen körülbelül saját sejtjeink számát teszik ki, ellentétben a régebben elfogadott $10: 1$ aránnyal [1]. A mikrobiom az emberi szervezetben élő mikrobák összessége, génjeik száma a sajátunkét több mint százszorosan meghaladja. Egyre több kutatás fókuszál összetételének és funkciójának megismerésére, hogy a jövőben betegeink javára befolyásoljuk azokat [2]

Az emberi mikrobiom összetételének vizsgálata során kiderült, hogy egészséges emberek között is jelentős különbségek lehetnek. Egy kutatás alapján az etnikai hovatartozás bizonyult a legjelentősebb faktornak [3]. A sokszínűség okai nagyrészt még ismeretlenek, de öszszefüggésbe hozták a környezettel, a táplálkozással, a genetikával és a természetes szülés fontosságával. A bakteriális közösség diverzitása az együtt élő fajok sokszínúségét, fajgazdagságát jelenti. A korai mikrobaexpozíció következtében a mikrobiális diverzitás nő, aminek fontos szerepe van az immunrendszer fejlődésében. Császármetszéssel született csecsemőknél nagyobb a kockázat az élet során asztma, gyulladásos bélbetegség, fiatalkori rheumatoid arthritis, immundeficientia és leukaemia kialakulására [4]. A kolonizáló fajok összetételét az eltérő anatómiai lokalizáció, páratartalom, lokális immunfolyamatok, aerob-anaerob körülmények, hőmérséklet, a régiót borító hám elszarusodása és több más tényező együttesen befolyásolja. A mikrobák által alkotott közösség valamelyest stabil, és a symbiosisban élő fajok fiziológiásan egyensúlyban vannak. Dysbiosisról beszélünk, ha a mikrobák közötti egyensúly felborul, és új összetételű mikrobiom keletkezik. Ez a leggyakrabban akkor történik meg, ha a külvilágból egy patogén baktérium támadja meg a szervezetet. Másik útja a dysbiosis kialakulásának, ha a közösségben ható „erőegyensúly” változik meg, és a szervezet számára előnyös fajok száma csökken. Ismeretes, hogy antibiotikumterápia után a bél, illetve a hüvely normálflórája megváltozik, és ez jellemző tünetekkel járhat. A széles spektrumú antibiotikumhasználat után fellépő, Clostridium difficile okozta hasmenés jellegzetes példája a dysbiosisnak. A bélflóra egyensúlyának megbomlása a $C$. difficile túlszaporodásához vezet, ami súlyos hasmenés, láz és colitis kialakulásában nyilvánulhat meg [5].

A mikrobákkal való kapcsolatunknak számos ismert előnye van, például segítik egyes vitaminok felszívódását, és részt vesznek a szénhidrát-anyagcserében is. Nemcsak lokális, hanem a szervezet egészére kifejtett hatásukat is bebizonyították. Több mint 100 trillió mikroorganizmus található a bélrendszerben, így nem meglepő, hogy a legtöbb kutatás a gastrointestinalis mikrobiom megismerésére összpontosított, és erről áll rendelkezésre a legtöbb adat. A bélrendszeri mikrobiomnak szerepe van az immunrendszer fejlődésében, az immuntolerancia kiala- kulásában, így érthető, hogy az allergiás, autoimmun és gyulladásos betegségek patomechanizmusában elfoglalt helyét számos kutatás vizsgálja. Egyensúlyának felborulását szoros összefüggésbe hozták gastrointestinalis betegségekkel, mint az irritábilisbél-szindrómával és a gyulladásos bélbetegségekkel. A szisztémás betegségek közül az obesitassal, atópiával, 2-es típusú diabetes mellitussal sikerült kapcsolatba hozni $[6,7]$. A diverz, komplex összetételú bélrendszeri mikrobiom az egészséges állapotra jellemző, míg a csökkent diverzitású flóra a betegségekre [3].

Újabban egyre több fül-orr-gégészeti kutatás célozza a helyi mikrobiom összetételének, szerepének megismerését különböző betegségekben. Azt az egyszerű koncepciót, hogy egy betegség egyetlen patogén és a szervezet közötti interakció útján jön létre, felváltotta egy komplexebb szemlélet, amely a mikrobák egymás közötti és a szervezettel való kapcsolatával foglalkozik. Jelentőségét az adja, hogy a fül-orr-gégészeti infekciók a leggyakoribb fertőző betegségek az emberi szervezetben és az antibiotikumfelírás vezető okai világszerte. A gyerekek kb. 70\%-a 3 éves korig átesik legalább egyszer akut középfülgyulladáson [8].

A baktériumok kimutatása történhet hagyományosan tenyésztéssel, azonban egyes baktériumok speciális táptalajigénye korlátozza a detektálást, és kis csíraszám esetén sem hatásos módszer. A molekuláris biológiai módszereknek igen magas a szenzitivitásuk, ezért a negatív tenyésztési eredményű esetekben is jó eséllyel kimutatható a patogén baktérium. Polimeráz-láncreakció (PCR) során egy primer adott szekvenciához kötődése után az azt követő dezoxiribonukleinsav (DNS)- vagy ribonukleinsav (RNS)-szakaszt ciklusokban sokszorosítjuk. Baktériumok kimutatására a $16 \mathrm{~S}$ riboszomális ribonukleinsavat (16S rRNS) használjuk, mely a prokaryota riboszóma 30S alegység egy komponense. Tartalmaz az evolúció során egy erősen konzervált régiót és több hipervariábilis régiót. A $16 \mathrm{~S}$ rRNS a proteinszintézishez nélkülözhetetlen, ezért minden baktériumban megtalálható. A konzervált régiója minden baktériumban azonos, így ha a primer e régióhoz kapcsolódik, akkor a mintában lévő összes bakteriális RNS-t sokszorosíthatjuk. A prokaryoták 16S RNS hipervariábilis régiója fajonként eltérő szekvenciájú, így ez a régió alkalmas a baktériumok azonosítására. Újgenerációs szekvenálással a PCR során már felsokszorosított mintából a 16S rRNS hipervariábilis régió bázisszekvenciáját határozzuk meg, ez alapján azonosíthatjuk a baktériumokat. E módszer segítségével arról is információt kapunk, hogy az adott mintában melyek a legnagyobb számban megtalálható baktériumfajok. Az újgenerációs szekvenálás lehetővé tette, hogy a mintában jelen lévő összes fajt azonosítsuk előzetes hipotézis nélkül. Ritka, más módszerrel nehezen kimutatható baktériumokat, vírusokat vagy gombákat detektálhatunk a nehezen tisztázható mikrobiológiai közösségekben. 


\section{Fülészeti mikrobiom}

A fül részei közül a hallójárat van a leginkább összeköttetésben a külvilággal és az onnan származó baktériumokkal. A hallójárat egészsége és az azt benépesítő baktériumok összetétele a pH-tól, a nedvességtől, a cerumen mennyiségétől függ. Fiziológiásan is számos mikroorganizmus népesíti be a hallójáratot, de ez önmagában nem hajlamosít betegségre. Egy nagy elemszámú texasi kutatásban egészséges alanyok hallójáratából és a cerumenből vett minta tenyésztése során 98\%-ban Gram-pozitív baktériumokat izoláltak. A Gram-pozitív baktériumok közül Staphylococcus auricularis tenyészett ki a leggyakrabban [9]. Egy norvég kutatás tenyésztéses módszerrel szintén a Staphylococcus spp.-t, ezek között is a Staphylococcus epidermidist találta a leggyakoribb mikrobának a külső fülben. Az eddigi tanulmányok megegyeznek abban, hogy a hallójáratban a Corynebacteriumok a második leggyakrabban megtalálható baktériumcsalád [10, 11]. Újgenerációs szekvenálást alkalmazva az egészséges hallójáratban az Alloiococcus otitidis, Corynebacterium otitidis és $S$. auricularis dominált, együttesen a klónok $86 \%$-át tették ki. Ha egy alanynál az $A$. otitidis relatív alacsony csíraszámban volt jelen, akkor a $S$. auricularis relatív nagyobb mértékben elszaporodott. Ez a megfigyelés megerősíti azt, hogy a normálflóra tagjai egymással versenyeznek, és egy faj háttérbe szorulása más fajok elszaporodását vonja maga után [12].

Az akut otitis externa, a külső hallójárat gyulladása a leggyakrabban bakteriális eredetú. Heward és munkatársainak az Egyesült Királyságban végzett multicentrikus kutatásában többségében Pseudomonas aeruginosa (31\%) és Staphylococcus aureus (12\%) tenyészett ki a gyulladt hallójáratból. Az antibiotikumrezisztencia vizsgálata azt mutatta, hogy a $P$. aeruginosa-törzsek továbbra is érzékenyek voltak ciprofloxacinra, viszont a gentamicinrezisztencia növekedett. A korábbi adatokhoz képest a Candida spp. magasabb arányát (23\%) találták. A gombák régiónként eltérő előfordulását többek között az eltérő páratartalom magyarázhatja [13]. A betegségek hátterében álló patogének területi eltéréseit mutatja, hogy míg az Amerikai Egyesült Államokban, az Egyesült Királyságban a $P$. aeruginosa, $S$. aureus a leggyakoribb patogének otitis externában, egy nemrégiben közölt közelkeleti vizsgálat során a Bacillus spp.-t izolálták a leggyakrabban $[13,14]$.

A középfület a XXI. századig sterilnek tekintették [15]. Először egy 2009-es új-zélandi elektronmikroszkópos vizsgálat [16] során sikerült kimutatni egészséges középfülben baktériumokat, sőt biofilmfragmentumokat is, azonban konkrét baktériumot nem határoztak meg. Egy 2017-es multicentrikus kohorsztanulmányban [17] Japánban és az Egyesült Államokban vizsgálták a normálközépfül flóráját (1. táblázat) [17-19]. A leggyakrabban elóforduló phylum a Proteobacterium volt, majd gyakoriságban az Actinobacterium, a Firmicutes és a Bacteroidetes követte.
1. táblázat |A középfül jellemző bakteriális flórája egészséges és kóros álla potokban [17-19]

\begin{tabular}{lll}
\hline & Normálflóra & Kóros állapot \\
\hline Középfül & Phylum: & Krónikus savós otitis media: \\
& Proteobacterium $(57 \%)$ & Haemophilus influenzae a \\
Actinobacterium $(28 \%)$ & predomináns baktérium [19]; \\
Firmicutes $(19 \%)$ & egyéb jellemző: \\
Bacteroidetes $(3 \%)$ & nasopharynxban kevesebb \\
{$[17]$} & Corynebacterium-és Dolo- \\
& sigranulum-arány [18] \\
& Krónikus gennyes otitis media: \\
& Pseudomonas aeruginosa, \\
& Staphylococcus aureus, Proteus, \\
& Klebsiella; \\
& egyéb jellemző: \\
& kevesebb Proteobacterium-, \\
& magasabb Firmicutes-arány \\
& {$[17]$} \\
\hline
\end{tabular}

Míg az antibiotikumkezelés indikációja elsősorban az akut gennyes középfülgyulladás, a savós középfülgyulladást is kezelik antibiotikumokkal, dekongesztánsokkal, ezek kombinációjával, valamint időnként csak obszerválják. A savós középfülgyulladás a gyermekkori halláscsökkenés egyik leggyakoribb oka, megelőzése kulcsfontosságú a normális beszédfejlődés, kommunikáció, hangfeldolgozás és kognitív fejlődés érdekében. Kialakulása a fülkürt múködészavarához köthető, de pontos patogenezise máig ismeretlen. Az esetek nagy részében három hónap alatt spontán gyógyulás várható, de 3040\%-ban hat hétnél tovább fennálló, tehát krónikus savós középfülgyulladás alakul ki [20]. Megválaszolatlan kérdés, hogy mi vezet a krónikus gyulladás, illetve rekurráló savós középfülgyulladások létrejöttéhez. A mikrobiom szerepét mutatja, hogy a hosszabb ideig anyatejjel táplált csecsemőknél jelentősen ritkábban alakul ki rekurráló otitis media. Az antibiotikumok használata a normálflóra károsítása révén dysbiosishoz vezet, ennek megfelelően a közelmúltban antibiotikumterápián átesett betegek esetében nagyobb a valószínúsége a rekurráló serosus otitis media kialakulásának [18].

$\mathrm{Az}$ akut otitis media hátterében álló három leggyakoribb kórokozó a Streptococcus pneumoniae, a Haemophilus influenzae és a Moraxella catarrhalis. Az eddigi öszszefoglaló tanulmányok szerint a terápiarezisztens, illetve krónikus serosus otitis mediában a $H$. influenzae a predomináns baktérium [19]. A középfülbe a kórokozók jelen tudásunk szerint a hallójárat, illetve az orrgarat felől juthatnak. Megfigyelték, hogy a középfülgyulladásra hajlamos gyerekek orrgaratában több patogén baktérium található meg, és kevesebb a potenciálisan 'protektív' baktérium, mint a Prevotella, a Peptostreptococcus és az alfa-hemolizáló Streptococcus. Az alfa-hemolizáló Streptococcusok közül a leginkább ígéretes jelölt probiotikum fejlesztésére a Streptococcus salivarius $\mathrm{K}_{12}$-es törzse. Ez két, megaplazmidon kódolt fehérjét szekretál: a salivaricin A2-t és a salivaricin B-t, amelyek a S. pneumoniae, 
a $S$. pyogenes és a $M$. catarrhalis szaporodását gátolják. Per os alkalmazva csökkentette a savós középfülgyulladás ismételt kiújulását, javította a betegség kimenetelét, mindezek mellett biztonságosnak bizonyult az alkalmazása gyerekeknél [21]. Streptococcus sanguinis-, illetve Lactobacillus rhamnosus-törzseket tartalmazó orrspray használatával szintén ígéretes eredményeket értek el krónikus savós otitis media kezelésében, ugyanis a probiotikumos orrspray jelentősen növelte a gyógyulás esélyét. A vártakkal ellentétben azonban a terápia előtti és utáni orrgarati patogének populációjában nem találtak jelentős különbséget. Emellett az alkalmazott protektív baktériumot sem lehetett kitenyészteni a legtöbbször az orrgaratból a terápia után, így a pontos hatásmechanizmusra nem találtak magyarázatot [22]. Lappan és mtsai újgenerációs szekvenálással egészséges egyének orrgaratmintáiban jelentősen magasabb Corynebacterium-és Dolosigranulum-arányt találtak, mint a rekurráló középfülgyulladásban szenvedő betegeknél, ami egyértelműen felveti ezen baktériumok protektív szerepét. A bélrendszernél leírt összefüggéssel ellentétben az eddigi adatok alapján egészséges középfülstatus mellett csökkent diverzitású nasopharyngealis flórát figyeltek meg [18].

A purulens krónikus középfülgyulladás két fajtája a mesotympanalis és cholesteatomás otitis media; közös jellemzőjük a tartós fülfolyás, illetve a vezetéses halláscsökkenés. A cholesteatoma fültükri képében perforációnak látszó hámzsákszájadék figyelhető meg. A cholesteatoma a középfülben lévő keratinnal teli hámzsák, mely destruktív terjedése által súlyosan károsítja a középfül képleteit, mint például a hallócsontok, az arcideg csontos csatornája vagy a belsőfül csontos kapszulája. A mesotympanalis formánál valódi perforáció látható, és a gyulladás jól körülhatárolt, nem érinti a csontos falat. A cholesteatoma kialakulására számos elmélet született, például széles körben elfogadott a „retrakciós hámzsák” teória, mely a fülkürt krónikus múködészavarán alapul. A XIX. században elterjedt „metaplázia” teória szerint a középfüli mucosa alakul át elszarusodó laphámmá, aminek hátterében krónikus gyulladást vagy irritációt feltételeztek. Egyre több kutatás támasztja alá, hogy az idült középfülgyulladás kialakulásában meghatározó tényező a kolonizáló baktériumok patogenitása, illetve a szervezet ellenállási képességének csökkenése [23]. Patogenezisét a megzavart dobüregi bakteriális homeosztázis is magyarázhatja. Krónikus gennyes középfülgyulladásban a P. aeruginosa, a S. aureus, a Proteus és a Klebsiella a leggyakrabban kitenyésző baktériumok [17]. A betegség genetikai eredetét vizsgálva több, krónikus középfülgyulladásra hajlamosító gént azonosítottak. Egy Fülöpszigeteki kutatásban egy korábban azonosított, prediszponáló gént hordozó egyéneknél jellemző mikrobiomprofilt találtak. A mutáns gént hordozók között nagyobb volt a Fusobacterium, a Bacteroidetes, a Porphyromonas és a Parvimonas előfordulási aránya, míg az Alloiococcus, a Staphylococcus, a Proteus és a Haemophilus a vad típusú genetikájú egyének középfüleiben volt meghatározóbb.
Ezek az eredmények rávilágítanak arra, hogy a normálflóra összetétele már a génjeinkben meghatározott [24]. Egészséges és beteg populáció középfüli mikrobiomját összehasonlítva az figyelhető meg, hogy akiknél krónikus középfülgyulladás áll fenn aktív gyulladással, kevesebb a Proteobacterium és magasabb a Firmicutes előfordulási aránya a középfülben, mint az egészséges populációban [17]. Tympanosclerosisban a gyulladás következtében kalcifikált kollagén fibroticus szövet halmozódik fel a középfülben, és ez vezet halláscsökkenéshez. A cholesteatomában és tympanosclerosisban szenvedő betegek baktériumflórájának összehasonlításakor igen hasonló baktérium-összetételt találtak. Lehetséges, hogy bizonyos baktériumok együttes kolonizációja a krónikus gyulladás kialakulására prediszponál [25].

\section{Az orr- és orrmelléküregi mikrobiom}

Az orrüregi mikrobiom vizsgálatakor az orrüreg speciális felépítésének következtében a mintavétel pontos helye nagy szereppel bír. A melléküregi kivezetőnyílásokhoz és az orrbemenethez való közelségtől függően a bakteriális közösségek összetétele helyenként jelentôsen különbözhet [26]. Az orrüregi mikrobiom kialakításában a hőmérsékletnek is szerepe van: míg a vestibulum nasit kolonizáló baktériumok a környezeti hőmérsékletnek vannak kitéve, addig az orrkagylók területén a hőmérséklet emelkedik, a nasopharynxot elérve a levegő $34^{\circ} \mathrm{C}$ ot ér el, és a páratartalom is jelentősen megnő. A többmagsoros csillószőrös hengerhámon lévő ciliumok irányítják a mucinréteg mozgását a nasopharynx felé. A mucinban számos antimikrobiális protein található, mint például peroxidáz, lizozim és lipidkötő proteinek [27]. A baktériumok maguk is termelnek fehérjéket, amivel egy másik faj szaporodását gátolják vagy elősegítik. A fülészeti mikrobiomnál megfigyeltek szerint az orrüregben is sikerült egymással versengő fajokat azonosítani. Egy tanulmány eredményei azt mutatták, hogy a Streptococcus spp.-negatív gyermekeknél a Corynebacteri$u m$ nagyobb arányban tenyészik ki. In vitro modellben a Corynebacterium accolens hidrolízise következtében felszabaduló oleinsav gátolta a Streptococcus pneumoniae növekedését [28]. Hasonló negatív kölcsönhatást figyeltek meg a $S$. epidermidis és a $S$. aureus között [29].

$\mathrm{Az}$ egészséges orrmelléküreg flóráját tekintve nincs konszenzus arra vonatkozóan, hogy melyik a leggyakrabban előforduló mikroba, de az eddigi tanulmányok alapján összefoglalva a Propionibacterium acnes, a $S$. epidermidis, a $S$. aureus és a Corynebacteriumok a flóra legjellemzőbb tagjai (2. táblázat) [26, 29]. Az orrüreg és orrmelléküregek baktérium-összetételét összehasonlítva ugyanazon phylumok dominanciáját találták, de azok relatív előfordulási aránya eltért. Érdekes megfigyelés, hogy több légúti patogén megtalálható egészséges egyének orrüregében. Feltételezhető, hogy a patogének a rezidens vagy tranziens flóránk tagjai, azonban a többi 
2. táblázat $\mid$ Az orrüreg és orrmelléküregek jellemző bakteriális flórája egészséges és kóros állapotokban [26, 29]

\begin{tabular}{lll}
\hline & Normálflóra & Kóros állapot \\
\hline Orrüreg, & Phylum: & Krónikus rhinosinusitis \\
orrmellék- & Actinobacterium $(51 \%)$ & jellemzője: \\
üregek & Firmicutes $(25 \%)$ & magasabb S. aureus- és \\
& Proteobacterium $(21 \%)$ & anaerobbaktérium-arány \\
& Bacteroidetes $(3 \%)$ & {$[29]$} \\
& Nemzetség: & \\
& Propionibacterium acnes, \\
& Corynebacterium, & \\
& Staphylococcus [26] & \\
\hline
\end{tabular}

mikroba és immunrendszerünk együttesen akadályozza elszaporodásukat [26].

A krónikus orrmelléküreg-gyulladás az orrüreg, orrmelléküregek elhúzódó gyulladása, tünetei az orrváladékozás, az orrlégzési gátoltság, a szaglás gyengülése és arcfájdalom lehetnek. Az Egyesült Államokban az egyik leggyakoribb egészségügyi problémák között áll. A patogenezisében szerepet játszó faktorok között eddig ismertek a szervezeti (például allergia, anatómiai felépítés, immundeficientia) és a környezeti (például baktériumok, vírusok, pollenek) tényezők. A krónikus rhinosinusitis etiológiájára számos teória született, melyek a mikrobák szerepét helyezik előtérbe. Gombák minden ember orrüregéből kimutathatók; egy elmélet szerint a gombák antigénjeire adott immunválaszunk játszhat szerepet a gyulladásos folyamat fenntartásában. Baktériumok is megtalálhatók mind az egészséges, mind a krónikusan gyulladt orrmelléküreg-rendszerben. A szuperantigénelmélet, a biofilmelmélet és a mikrobiom-elmélet tartozik a bakteriális kiindulású teóriák közé. A szuperantigén-elmélet szerint a $S$. aureus által termelt exotoxinok váltják ki a betegségre jellemző T- és B-sejt-proliferációt és citokinszekréciót. Mivel egészséges egyénekben is gyakran kimutatható a $S$. aureus, így inkább csak közrejátszó tényezőként fogadható el a szuperantigén szerepe [30]. Míg rhinitis acutában számos egyértelmú patogént sikerült azonosítani, amely a kórkép kialakulásához vezet, addig a krónikus orrmelléküreg-gyulladáshoz nem köthető egyértelmúen egy mikroba sem [31]. A tisztázatlan etiológia ellenére gyulladáscsökkentőkkel és gyakran többszöri mütéttel kezeljük a betegeket. A gyulladáscsökkentésre alkalmazhatunk szteroidterápiát, illetve idetartozik a hosszú távú kis dózisú makrolidterápia is, amely immunmoduláló hatásával csökkenti a gyulladást. A felsorolt kezelések csak bizonytalan ideig csökkentik vagy szüntetik meg a panaszokat, ezért a lehetséges patomechanizmusok feltérképezése elengedhetetlen a terápiás protokollok fejlesztéséhez. Egy amerikai egyesült államokbeli kutatásban az egyéb fertőzés miatt alkalmazott antibiotikumterápiát összefüggésbe hozták a krónikus orrmelléküreg-gyulladás kialakulásával. Ezt a megfigyelést a középfülgyulladásoknál is ismertettük. Az antibiotikumhasználat növeli a szervezet fogékonyságát másodlagos nyálkahártya-infekciókra, mint a Candida albicans, a Clostridium difficile. Egyre több kutatás támasztja alá, hogy a dysbiosis létrejötte krónikus betegségek alapjául is szolgálhat. A két éven belüli antibiotikumhasználat a krónikus orrmelléküreg-gyulladás kialakulásának valószínűségét több mint megduplázta, és klinikai lefolyását is súlyosbította [32]. Általánosan elmondható, hogy krónikus gyulladásban gyakrabban figyelhető meg a $S$. aureus, illetve az anaerob kórokozók, mint egészséges orrüregben. A korábban a bélrendszernél megfigyeltekhez hasonlóan a fajok diverzitása is csökkent a betegségekben [29, 31]. Krónikus orrmelléküreggyulladásban is történtek kísérletek a dysbiosis helyreállítására. Lactobacillusok és Bifidobacteriumok keverékéből álló orrspray kéthetes alkalmazásával a kezdeti és a terápia utáni mikrobiom összetételében nem mutatkozott jelentős különbség, és a betegség kimenetelére sem volt hatással a kezelés [33]. A sikertelenséget az is magyarázhatja, hogy a probiotikumok hosszabb távú használata szükséges a terápiás hatás eléréséhez. Lactobacillusok hónapokon át egyszerre orrsprayként és per os történő alkalmazása tartós MRSA-hordozó pácienseknél a baktérium eradikációját eredményezte [34].

Mint ahogy korábban a bélrendszerben található mikrobiomról is bebizonyosodott, hogy allergiás betegségekben megváltozik az összetétele [7], úgy az orrüregi mikrobiom dysbiosisát is nemrég sikerült kapcsolatba hozni az allergiás náthával. Az embert kolonizáló mikrobaközösség egyensúlyának felborulása lymphocyta és eosinophil granulocyta infiltrációjához, Th1-Th2 eltolódáshoz, regulátor-T-sejt-csökkenéshez vezet, így növeli az allergia iránti fogékonyságot. Az alsó orrkagylók a környezeti allergének első barriere. Az allergiás, duzzadt orrkagylók epithelsejtjeinek megnő a permeabilitása és citokinexpressziója, ami folyadék szekréciójához vezet. Az orrüregben létrejövő megnövekedett mennyiségű váladék befolyásolja a helyi baktériumok szaporodását, így visszahat a lokális mikrobiális közösség összetételére. A mikrobiom és az immunrendszer jelentős kölcsönhatásban van allergiás megbetegedések esetén, de ennek pontos patomechanizmusa máig ismeretlen. A bélrendszernél már kimutatott összefüggésnek megfelelően az allergiás rhinitis vizsgálatával is azt találták, hogy az orrüregi mikrobiom alacsony fokú diverzitása magasabb IgE-szinteknél figyelhető meg [35]. Ezekből az eredményekból az következik, hogy a baktériumflóránk pusztítása nemcsak gombás betegségekhez, hasmenéshez vezethet, hanem egyelőre nem tisztázott mechanizmuson keresztül hosszú távon kóros immunfolyamatokat indíthat be. Probiotikumok alkalmazása az allergiás betegségekben sikeresnek bizonyult. Egy átfogó metaanalízis szerint legalább négy hétig való használatuk jelentősen javítja a klinikai lefolyást [36].

\section{A szájüreg-, garat- és a gégemikrobiom}

A szájüreg az emésztőrendszer és a légutak közös bevezetője. A szájüreg változatos életteret jelent a mikrobák- 
3. táblázat $\mid$ A szájüreg, a garat és a gége jellemző bakteriális flórája egészséges és kóros állapotokban [37-42]

\begin{tabular}{|c|c|c|}
\hline & Normálflóra & Kóros állapot \\
\hline Szájüreg & $\begin{array}{l}\text { Phylum: } \\
\text { Firmicutes (37\%) } \\
\text { Bacteroidetes }(17 \%) \\
\text { Proteobacterium (17\%) } \\
\text { Actinobacterium (12\%) } \\
\text { Spirocheták }(8 \%) \\
\text { Fusobacterium (5\%) } \\
\text { [37] } \\
\text { Nemzetség: } \\
\text { Streptococcus, Veillonella, } \\
\text { Gemella, Rothia, Fusobacte- } \\
\text { rium, Neisseria [38] }\end{array}$ & $\begin{array}{l}\text { Oropharyngealis carcinoma } \\
\text { jellemzöje: } \\
\text { magasabb Actinomyces-, } \\
\text { Schwartzia-, Treponema-, } \\
\text { Selenomonas-arány [38] }\end{array}$ \\
\hline Garat & $\begin{array}{l}\text { Phylum: } \\
\text { Firmicutes }(44 \%) \\
\text { Bacteroidetes }(27 \%) \\
\text { Actinobacterium }(11 \%) \\
\text { Proteobacterium }(10 \%) \\
\text { Fusobacterium }(8 \%) \\
\text { Nemzetség: } \\
\text { Prevotella, Capnocytophaga, } \\
\text { Campylobacter, Veillonella, } \\
\text { Streptococcus, Neisseria, } \\
\text { Haemophilus [39] }\end{array}$ & $\begin{array}{l}\text { Rekurráló felső légúti } \\
\text { fertőzés jellemzője: } \\
\text { magasabb Proteobacterium-, } \\
\text { alacsonyabb Bacteroidetes- } \\
\text { arány [39] }\end{array}$ \\
\hline Gége & $\begin{array}{l}\text { Phylum: } \\
\text { Firmicutes }(54 \%) \\
\text { Fusobacterium }(17 \%) \\
\text { Bacteroidetes }(15 \%) \\
\text { Proteobacterium }(11 \%) \\
\text { Actinobacterium }(3 \%) \\
\text { Nemzetség: } \\
\text { Streptococcus, Fusobacteri- } \\
\text { um, Prevotella, Neisseria, } \\
\text { Gemella }[40]\end{array}$ & $\begin{array}{l}\text { Krónikus laryngitis: } \\
\text { Staphylococcus aureus, } \\
\text { Haemophilus influenzae, } \\
\text { Candida albicans, } \\
\text { Moraxella nonliquefa, } \\
\text { Propionibacterium acnes, } \\
\text { Neisseria meningitidis, } \\
\text { S. pneumoniae [41] } \\
\text { A dohányzás jellemzője: } \\
\text { magasabb Streptococcus- } \\
\text { arány [42] }\end{array}$ \\
\hline
\end{tabular}

nak: a nyelv, a fogak, a bucca, a lágyszájpad, és a mandulák tartoznak e régióba. A szájüregben jellemzően hat phylum: Firmicutes, Bacteroidetes, Proteobacterium, Actinobacterium, Spirocheták és Fusobacteriumok fordulnak elő. Nemzetségszinten a Streptococcus a leggyakoribb, utána követi a Veillonella, a Gemella, a Rothia, a Fusobacterium és a Neisseria (3. táblázat) [37-42]. A nyelv részei különböző mértékű elszarusodásának következménye az eltérő mikrobiális közösségek kialakulása a nyelv különböző felszínein. A nyálmirigyek múködése, az azok kivezetócsatornáihoz való közelség meghatározza a helyi környezet $\mathrm{pH}$-ját, nedvességét és proteintartalmát. Ennek köszönhetően az egyes fogakon jelentősen eltérő komponensű biofilm található. A nyálmirigy-kivezetőcsövek közelében a Proteobacteriumok kisebb számban, míg a Bacteroidetes nagyobb számban található meg. E két baktérium szerepe ismert a fogszuvasodás kialakulásában, ezért nem meglepő, hogy a nyálmirigyek csökkent múködése rövid távon fogszuvasodáshoz vezet [37].
A garatban a Humán Mikrobiom Projekt öt fó baktériumphylumot határozott meg: Bacteroidetes, Proteobacterium, Actinobacterium, Fusobacterium és Firmicutes. A helyenként eltérő anatómiai tényezők jelentősen befolyásolják a különböző fajok lokális előfordulását. Nehéz a garatra egyedi baktériummintát találni, de a Haemophilus, a Neisseria, a Prevotella, a Capnocytophaga, a Streptococcus, a Campylobacter és a Veillonella nevezhetók a leggyakrabban előforduló nemzetségnek. A garatban uralkodó nedves környezet patogén baktériumoknak is ideális szaporodási feltételeket biztosít, ezért megtalálhatjuk őket a rezidens flóra tagjai között tünetmentes egyéneknél is. Visszatérő légúti fertőzéssel küzdő betegek mikrobiom-vizsgálatakor az figyelhető meg, hogy a Bacteroidetes phylum visszaszorulásával a számos patogént tartalmazó Proteobacteriumok kerülnek előtérbe [39]. A szervezet jó általános állapota és az epithelsejtek megfelelő funkciója alapvető feltétele az egészséges normálflóra fenntartásának. Az epithel funkciózavarakor, például cystás fibrosisban a patológiás bélflórára jellemző összefüggést találunk: csökken a mikrobiom diverzitása, és nő a patogének száma [43]. A szájgarati diverz, sokszínú mikrobiális közösségnek tehát szerepe van a patogének szaporodásának meggátlásában. Ha a normálflóra valamilyen okból veszít a fajgazdagságából, megnő a veszélye a patogének túlsúlyba kerülésének. A Fusobacterium necrophorum okozta torokgyulladás vizsgálatakor kimutatták, hogy a garat mikrobaközösségének fajgazdagsága a betegségben jelentősen csökkent [44]. Az eddig ismertetett fül-orr-gégészeti régiókhoz hasonlóan a garatban élő baktériumok között is megfigyelhető versengés és egymás kiszorítása az élőhelyről. Az alfa-hemolizáló Streptococcusok bakteriocin termelése révén gátolják az A-csoportú béta-hemolizáló Streptococcusok növekedését. A mandulagyulladásban alkalmazott penicillinterápia sikertelenségét az magyarázhatja, hogy a szintén elpusztított alfa-hemolizáló Streptococcusoknak szerepük van a béta-hemolizáló Streptococcusok eradikációjában. A mindennapi gyakorlat számára releváns megállapítás, hogy az alfa-hemolizáló Streptococcusok ellenállóbbak a cefalosporinokkal szemben, ezért akut tonsillitis cefalosporinkezelésével eredményesebb patogéneliminációval számolhatunk, mint penicillinterápiában. A normálflóra tehát kevésbé sérül cefalosporinok alkalmazásával, így kevesebb mellékhatás várható [45]. A garat betegségeinek kezelésekor szintén ígéretes lehetőség a probiotikumterápia. A fülészeti mikrobiomnál ismertetett $S$. salivarius $\mathrm{K}_{12}$ probiotikumként alkalmazva egy olasz kutatásban az akut középfülgyulladás és a Streptococcus okozta tonsillopharyngitis incidenciáját egyaránt csökkentette [46].

A mikrobiom szerepét egyre több betegségben sikerül kimutatni, ezzel párhuzamosan a daganatos megbetegedéseknél is felismerték az összefüggést a bakteriális diverzitás csökkenésével. A krónikus gyulladás fennállása fontos rizikótényező a daganatok kialakulásában. A mikrobiom krónikus betegségekkel való összefüggésének bizo- 
nyítása után egyenes út vezetett a rosszindulatú daganatos betegségek kutatásához. A mikrobák és az általuk kiválasztott anyagok (enzimek, metabolikus termékek, endotoxinok) aktiválhatják az immunrendszert. Az így aktiválódott immunsejtek által termelt oxigén-szabadgyökök, gyulladásos citokinek, reaktívnitrogén-származékok károsítják a helyi mucosát. A szöveti károsodás hatására bekövetkező felgyorsult sejtosztódás során protoonkogének és tumorszuppresszor gének mutációja következhet be. Egyes mikrobák epithelkárosodáson keresztüli karcinogén hatását már kimutatták, mint például Helicobacter pylori, EBV, hepatitis $C$, azonban a betegségek kialakulására vonatkozó „egyetlen patogén” elmélet az onkológiában is megdőlni látszik [38]. A bélflóra tanulmányozásakor 2012-ben megfigyelték, hogy a Fusobacterium nucleatum kóros túlsúlya jellemző vastagbéldaganatokban. A mikrobiom és a daganatos betegségek kapcsolatát állatmodellben vizsgálva bebizonyították, hogy a bélflóra dysbiosisa a karcinogenezisben szerepet játszó jelátviteli útvonalakat indít be [47]. Az egészséges és a daganatos flóra megismerése felveti annak lehetőségét, hogy a mikrobiom változásainak kimutatásával a jövőben tumorokat diagnosztizálhatunk, akár a terápiakészségre, prognózisra következtethetünk. A nyálminta egyszerúen hozzáférhető, így felveti a neminvazív diagnosztika lehetőségét. Daganatos betegségekben a nyálból kimutatható bakteriális markerek azonosítását az utóbbi években egyre több kutatás célozza. Yan és mtsai tüdődaganatos betegek szájüregi mikrobiomját egészséges populációéval összehasonlítva két baktérium, a Capnocytophaga és a Veillonella gyakoribb előfordulását észlelték. Biomarkerként használva e két baktériumot, 85\%-os szenzitivitással és $87 \%$-os specificitással lehetett megkülönböztetni a tüdődaganatos betegeket a kontrollcsoporttól [48]. Wolf és mtsai kimutatták, hogy oropharyngealis carcinomában a szájüreg bakteriális öszszetételében egészséges populációhoz képest az Actinomyces, a Schwartzia, a Treponema és a Selenomonas nagyobb előfordulási aránya figyelhető meg [38].

A légutak bevezető kapujaként a gégét érinti elsősorban a gyomorsav, a belélegzett és a lenyelt irritáló anyagok és baktériumok. Az egészséges gégében a Firmicutes, a Fusobacterium, a Bacteroidetes, a Proteobacterium és az Actinobacterium a leggyakrabban előforduló phylumok, nemzetségszinten a Streptococcus, a Fusobacterium, a Prevotella, a Neisseria és a Gemella [40]. A krónikus gégegyulladás etiológiai faktorai közé tartozik a dohányzás, a reflux, az allergia vagy a hangszálak megerőltetése. A dysbiosis szerepét a gégegyulladás kialakulásában megerősíti, hogy krónikus gégegyulladásban jelentős biofilmképződést lehet megfigyelni. A biofilmképzésben a $S$. aureus, a $H$. influenzae, a C. albicans, a Moraxella nonliquefa, a Propionibacterium acnes, a Neisseria meningitidis és a $S$. pneumoniae vesz részt [41]. A dohányfüst befolyásolja a bakteriális közösség összetételét, hiszen az aerob környezetet anaerob irányban eltolva feltehetően több, az obligát aerob normálflórához tartozó baktéri- um szaporodását gátolja. Ennek megfelelően a dohányosok gégemikrobiomjában a normálgégeflórának amúgy is a többségét alkotó fakultatív anaerob Streptococcus spp. még kifejezettebb túlsúlyát figyelték meg. A Streptococcus spp. nagymértékü elszaporodását gégedaganatokban már kimutatták, ami megerősíti, hogy a mikrobiális egyensúly kritikus fontosságú az egészséges gégenyálkahártya fenntartásához. A bélrendszernél, orrüregnél és garatnál megfigyelt jelenség, miszerint a patológiás állapotokhoz csökkent biodiverzitás társul, a gégénél is érvényesül [42].

\section{Terápiás lehetőségek}

Az egészséges mikrobiom fenntartása nemcsak a patogének visszaszorításában alapvető, hanem a szervezettel való kölcsönös kapcsolata miatt a betegségek lefolyásában is döntő fontosságú. A bélrendszeri mikrobiomról bebizonyosodott, hogy befolyásolja számos gyógyszer farmakokinetikáját, biohasznosulását, mellékhatását és hatásosságát [49]. Ennek alapján feltételezhető, hogy a fül-orr-gégészeti mikrobiom is hatással van a felső légúti betegségek kimenetelének és terápiájának hatékonyságára. További kutatások szükségesek, hogy a betegségek kialakulását elősegítő, illetve gátló mikrobákat azonosíthassuk. A krónikus betegségek kialakulásához vezető út megismeréséhez a szervezet és a mikrobaközösségek sokrétú kapcsolatának feltérképezésével jutunk közelebb. A patogenezisben részt vevő baktériumok azonosítása, illetve a mikrobiom specifikus változásainak feltérképezése lehetőséget nyújt új biomarkerek kutatására is. Elképzelhető, hogy a jövőben adott mikroba-összetételhez bizonyos betegségeket tudunk majd kötni, így könynyítve meg a diagnózis felállítását. Egyes baktériumok relatív túlsúlya alapján következtetni tudunk majd a prognózisra, a terápiás válaszkészségre. A mikrobák egymással való szinergista, illetve antagonista kapcsolatainak megismerésével értékes információhoz jutunk, hogy a jövőben a terápiás célpontokat kiválaszthassuk. A patogéneket gátló, a szervezet által jól tolerálható baktériumok szaporodásának serkentése ígéretes terápiás lehetőség. Új távlatok nyílnak a mikrobiom módosításával: probiotikumokkal kívülról fajokat telepíthetünk be, illetve antibiotikumokkal, specifikus inhibitorokkal más fajokat visszaszoríthatunk. A probiotikumok bevitelének különös példája a széklettranszplantáció, amellyel terápiarezisztens Clostridium difficile-fertőzés esetében 90\%-os gyógyulást lehet elérni. A széklettranszplantáció 2013-ban az amerikai irányelvbe is bevezetésre került mint alternatív terápiás lehetôség [50]. A széklettranszplantációval elért sikerek előrevetítik más szekrétumok, mint például nyál, orrváladék transzplantációjának lehetőségét. Számos kutatás fókuszál a betegségek ellen védő protektív baktériumok azonosítására, amelyeket később probiotikum formájában alkalmazhatunk a betegségek prevenciójában, kezelésében. 2017 óta Magyarországon is forgalomban van egy Streptococcus salivarius $24 \mathrm{SMBc}$ 
és Streptococcus oralis 89a törzseket tartalmazó orrspray, mely felsőlégúti fertőzések kezelésére és megelőzésére javallott. A jövő orrcseppjei, fogkrémjei, bőrápolási termékei baktériumokat, illetve prebiotikumokat fognak tartalmazni, ami segíthet majd többek között a középfülgyulladás, orrmelléküreg-gyulladás, fogszuvasodás, atópiás dermatitis, gyulladásos bélbetegségek gyógyításában, megelőzésében. A mikrobiom megismerése és befolyásolása utat nyit a személyre szabott terápia fejlődésének.

\section{Következtetések}

A leggyakoribb patogének globális és területi rendszeres vizsgálata szükséges annak érdekében, hogy a terápiás stratégiákat folyamatosan aktualizáljuk, és azokat a releváns kórokozókhoz és azok antibiotikumrezisztenciájához igazítsuk. A mikrobiom szerepének megismerése rámutatott arra, hogy a megfelelő antibiotikumterápiát nemcsak egy feltételezett patogén érzékenysége alapján érdemes kiválasztanunk, hanem a bakteriális közösséget egészében figyelembe kell vennünk. Ehhez feltétlenül szükséges mérlegelnünk, hogy szükséges-e az antibiotikum adása, és ha igen, akkor melyik az a legszúkebb spektrumú szer, amely a mikrobiom összetételét a legkedvezőbben módosítja a terápiás hatás érdekében.

Anyagi támogatás: A közlemény megírása anyagi támogatásban nem részesült.

Szerzôi munkamegosztás: A kézirat megírásában és az irodalom összeállításában minden szerző részt vett. A cikk végleges változatát valamennyi szerző elolvasta, jóváhagyta.

Érdekeltségek: A szerzőknek nincsenek érdekeltségeik.

\section{Irodalom}

[1] Sender R, Fuchs S, Milo R. Revised estimates for the number of human and bacteria cells in the body. PLoS Biol. 2016; 14: e1002533.

[2] Bull MJ, Plummer NT. Part 1: The human gut microbiome in health and disease. Integr Med. 2014; 13: 17-22.

[3] Huttenhower C, Gevers D, Knith R, et al., The Human Microbiome Project Consortium. Structure, function and diversity of the healthy human microbiome. Nature 2012; 486: 207-214.

[4] Magne F, Puchi Silva A, Carvajal B, et al. The elevated rate of cesarean section and its contribution to non-communicable chronic diseases in Latin America: the growing involvement of the microbiota. Front Pediatr. 2017; 5: 192.

[5] Sonnenburg JL, Fischbach MA. Community health care: therapeutic opportunities in the human microbiome. Sci Transl Med. 2011; 78: PS12.

[6] Barna I, Nyúl D, Szentes T, et al. Review of the relation between gut microbiome, metabolic disease and hypertension. [A bélmikrobiom, a metabolikus betegségek és a hypertonia kapcsolatának irodalmi áttekintése.] Orv Hetil. 2018; 159: 346-351. [Hungarian]
[7] McLoughlin RM, Mills KH. Influence of gastrointestinal com mensal bacteria on the immune responses that mediate allergy and asthma. J Allergy Clin Immunol. 2011; 127: 1097-1107.

[8] Teele DW, Klein JO, Rosner BA. Epidemiology of otitis media in children. Ann Otol Rhinol Laryngol Suppl. 1980; 89: 5-6.

[9] Stroman DW, Roland PS, Dohar J, et al. Microbiology of normal external auditory canal. Laryngoscope 2001; 111: 2054-2059.

[10] Dibb WL. The normal microbial flora of the outer ear canal in healthy Norwegian individuals. NIPH Ann. 1990; 13: 11-16.

[11] Campos A, Arias A, Betancor L, et al. Study of common aerobic flora of human cerumen. J Laryngol Otol. 1998; 112: 613-616.

[12] Frank DN, Spiegelman GB, Davis W, et al. Culture-independent molecular analysis of microbial constituents of the healthy human outer ear. J Clin Microbiol. 2003; 41: 295-303.

[13] Heward E, Cullen M, Hobson J. Microbiology and antimicrobial susceptibility of otitis externa: a changing pattern of antimicrobial resistance. J Laryngol Otol. 2018; 132: 314-317.

[14] Kiakojuri K, Mahdavi Omran S, Jalili B, et al. Bacterial otitis externa in patients attending an ENT Clinic in Babol, North of Iran. Jundishapur J Microbiol. 2016; 9: e23093.

[15] Westerberg BD, Kozak FK, Thomas EE, et al. Is the healthy middle ear a normally sterile site? Otol Neurotol. 2009; 30: 174177.

[16] Tonnaer EL, Mylanus EA, Mulder JJ, et al. Detection of bacteria in healthy middle ears during cochlear implantation. Arch Otolaryngol Head Neck Surg. 2009; 135: 232-237.

[17] Minami SB, Mutai H, Suzuki T, et al. Microbiomes of the normal middle ear and ears with chronic otitis media. Laryngoscope 2017; 127: E371-E377.

[18] Lappan R, Imbrogno K, Sikazwe C, et al. A microbiome casecontrol study of recurrent acute otitis media identified potentially protective bacterial genera. BMC Microbiol. 2018; 18: 13 .

[19] Ngo CC, Massa HM, Thornton RB, et al. Predominant bacteria detected from the middle ear fluid of children experiencing otitis media: a systematic review. PloS ONE 2016; 11: e0150949.

[20] American Academy of Family Physicians, American Academy of Otolaryngology-Head and Neck Surgery, American Academy of Pediatrics Subcommittee on Otitis Media With Effusion. Otitis media with effusion. Pediatrics 2004; 113: 1412-1429.

[21] Di Pierro F, Di Pasquale D, Di Cicco M. Oral use of Streptococcus salivarius $\mathrm{K}_{12}$ in children with secretory otitis media: preliminary results of a pilot, uncontrolled study. Int J Gen Med. 2015; 8: 303-308.

[22] Skovbjerg S, Roos K, Holm SE, et al. Spray bacteriotherapy decreases middle ear fluid in children with secretory otitis media. Arch Dis Child. 2009; 94: 92-98.

[23] Kuo CL. Etiopathogenesis of acquired cholesteatoma: prominent theories and recent advances in biomolecular research. Laryngoscope 2015 ; 125: 234-240.

[24] Santos-Cortez RL, Hutchinson DS, Ajami NJ, et al. Middle ear microbiome differences in indigenous Filipinos with chronic otitis media due to a duplication in the $A 2 M L 1$ gene. Infect Dis Poverty 2016; 5: 97.

[25] Kalcioglu MT, Guldemir D, Unaldi O, et al. Metagenomics analysis of bacterial population of tympanosclerotic plaques and cholesteatomas. Otolaryngol Head Neck Surg. 2018; 159: 724732 .

[26] Yan M, Pamp SJ, Fukuyama J, et al. Nasal microenvironments and interspecific interactions influence nasal microbiota complexity and S. aureus carriage. Cell Host Microbe 2013; 14: 631-640.

[27] Proctor DM, Relman DA. The landscape ecology and microbiota of the human nose, mouth, and throat. Cell Host Microbe 2017; 21 : 421-432.

[28] Bomar L, Brugger SD, Yost BH, et al. Corynebacterium accolens releases antipneumococcal free fatty acids from human nostril and skin surface triacylglycerols. mBio 2016; 7: e01725-15. 
[29] Ramakrishnan VR, Hauser LJ, Frank DN. The sinonasal bacterial microbiome in health and disease. Curr Opin Otolaryngol Head Neck Surg. 2016; 24: 20-25.

[30] Lam K, Schleimer R, Kern RC. The etiology and pathogenesis of chronic rhinosinusitis: a review of current hypotheses. Curr Allergy Asthma Rep. 2015; 15: 41.

[31] Copeland E, Leonard K, Carney R, et al. Chronic rhinosinusitis: potential role of microbial dysbiosis and recommendations for sampling sites. Front Cell Infect Microbiol. 2018; 8: 57.

[32] Maxfield AZ, Korkmaz H, Gregorio LL, et al. General antibiotic exposure is associated with increased risk of developing chronic rhinosinusitis. Laryngoscope 2017; 127: 296-302.

[33] Mårtensson A, Abolhalaj M, Lindstedt M, et al. Clinical efficacy of a topical lactic acid bacterial microbiome in chronic rhinosinusitis: a randomized controlled trial. Laryngoscope Investig Otolaryngol. 2017; 2: 410-416.

[34] Roos K, Simark-Mattsson C, Grahn Håkansson E, et al. Can probiotic lactobacilli eradicate persistent carriage of meticillin-resistant Staphylococcus aureus? J Hosp Infect. 2011; 78: 77-78.

[35] Hyun DW, Min HJ, Kim MS, et al. Dysbiosis of inferior turbinate microbiota is associated with high total IgE levels in patients with allergic rhinitis. Infect Immun. 2018; 86: e00934-17.

[36] Güvenç IA, Muluk NB, Mutlu FS, et al. Do probiotics have a role in the treatment of allergic rhinitis? A comprehensive systematic review and meta-analysis. Am J Rhinol Allergy 2016; 30: 157-175.

[37] Dewhirst FE, Chen T, Izard J, et al. The human oral microbiome. J Bacteriol. 2010; 192: 5002-5017.

[38] Wolf A, Moissl-Eichinger C, Perras A, et al. The salivary microbiome as an indicator of carcinogenesis in patients with oropharyngeal squamous cell carcinoma: a pilot study. Sci Rep. 2017; 7: 5867 .

[39] Gao Z, Kang Y, Yu J, et al. Human pharyngeal microbiome may play a protective role in respiratory tract infections. Genomics Proteomics Bioinformatics 2014; 12: 144-150.

[40] Gong HL, Shi Y, Zhou L, et al. The composition of microbiome in larynx and the throat biodiversity between laryngeal squamous cell carcinoma patients and control population. PLoS ONE 2013; 8: e66476.
[41] Kinnari TJ, Lampikoski H, Hyyrynen T, et al. Bacterial biofilm associated with chronic laryngitis. Arch Otolaryngol Head Neck Surg. 2012; 138: 467-470.

[42] Jetté ME, Dill-McFarland KA, Hanshew AS, et al. The human laryngeal microbiome: effects of cigarette smoke and reflux. Sci Rep. 2016; 6: 35882.

[43] Boutin S, Depner M, Stahl M, et al. Comparison of oropharyngeal microbiota from children with asthma and cystic fibrosis. Mediators Inflamm. 2017; 2017: 5047403.

[44] Atkinson TP, Centor RM, Xiao L, et al. Analysis of the tonsillar microbiome in young adults with sore throat reveals a high relative abundance of Fusobacterium necrophorum with low diversity. PloS ONE 2018; 13: e0189423.

[45] Brook I, Foote PA. Efficacy of penicillin versus cefdinir in eradication of group A streptococci and tonsillar flora. Antimicrob Agents Chemother. 2005; 49: 4787-4788.

[46] Di Pierro F, Colombo M, Giuliani MG, et al. Effect of administration of Streptococcus salivarius $\mathrm{K}_{12}$ on the occurrence of streptococcal pharyngo-tonsillitis, scarlet fever and acute otitis media in 3 years old children. Eur Rev Med Pharmacol Sci. 2016; 20: $4601-4606$.

[47] Rubinstein MR, Wang X, Liu W, et al. Fusobacterium nucleatum promotes colorectal carcinogenesis by modulating E-cadherin/ $\beta$-catenin signaling via its FadA adhesin. Cell Host Microbe 2013; 14: 195-206.

[48] Yan X, Yang M, Liu J, et al. Discovery and validation of potential bacterial biomarkers for lung cancer. Am J Cancer Res. 2015; 5: 3111-3122.

[49] Wilson ID, Nicholson JK. The role of gut microbiota in drug response. Curr Pharm Des. 2009; 15: 1519-1523.

[50] Gupta S, Allen-Vercoe E, Petrof EO. Fecal microbiota transplantation: in perspective. Therap Adv Gastroenterol. 2016; 9: 229239.

(Fekete Szilvia dr., Budapest, Szigony u. 36., 1083 e-mail: szilvia.a.fekete@gmail.com)

\section{„Ut sementem feceris, ita metes." (Cicero) (Ki mint vet, úgy arat.)}

A cikk a Creative Commons Attribution 4.0 International License (https://creativecommons.org/licenses/by/4.0/) feltételei szerint publikált Open Access közlemény, melynek szellemében a cikk bármilyen médiumban szabadon felhasználható, megosztható és újraközölhető, feltéve, hogy az eredeti szerző és a közlés helye, illetve a CC License linkje és az esetlegesen végrehajtott módositások feltüntetésre kerülnek. (SID_1) 